\title{
Comparison of nutrient components of Chinese lettuce (Lactuca sativa L.) and American lettuce
}

\author{
Shi Xueping ${ }^{1,2}$, Fang Yu', Caiyun Jiang', Hongtao Wang', Rui Yukui ${ }^{3,4 *}$ \\ ${ }^{1}$ Department of Engineerning and Technology of Jiangsu Institute of Comerce, 211168, Nanjing, Jiangsu Province, China; ${ }^{2}$ Department of \\ Food Science, University of Massachusetts, Amherst, MA 01003, USA; ${ }^{3}$ College of Resources and Environmental Sciences, China Agricultural \\ University, Beijing 100193, China; ${ }^{4}$ Stockbridge School of Agriculture, University of Massachusetts, Amherst, MA 01003, USA
}

\section{A B S TR A C T}

Food preference affects the human health and food species, and different countries have different food preference and habits. Lettuce was selected to study the effects of food preference on the food nutrition of Chinese foods and American foods. The results showed that the Chinese lettuce can store much less time than the American lettuce, which should be caused by that Chinese lettuce has more leaves and less stalks than American lettuce, and Chinese lettuce contain more moisture. Chinese lettuce significantly contained more protein and fatty acids than American lettuce, but contained less carbohydrate and dietary fiber; and concentrations of most trace elements $(\mathrm{Ca}, \mathrm{Fe}, \mathrm{Zn}$, Se and $\mathrm{Cu}$ ) in Chinese lettuce were significantly higher than American lettuce except Mn. The suggestion is that the different varieties of lettuce should be exchanged for food, which can make the human body nutritional balance of Protein, fatty acids, carbohydrate, dietary fiber.

Keywords: Food preference; Lettuce; Nutrient components; China; USA; Trace elements

\section{INTRODUCTION}

Comprehensive nutrition is a prerequisite to ensure the human health, if a certain nutritional intake is insufficient or excessive, will cause many corresponding diseases. Human nutrients are got mainly through food intake, so food habits and preferences will affect people's health (Velardo, 2015) and even life span (Kim et al., 2012). Food habits and preferences are different in different regions or different countries, which could be an important reason of local diseases (Gerber and Tessier, 2009).

People from China, as a famous country for foods, in the diet culture, more focus on the color, flavor and nutrition of foods than people from USA; and people from the United States much more focus on the quickness and convenience of foods, at the same time, they also pay more attention to the shelf life of the foods. Because of these different requirements for the foods, so the food varieties, cooking methods in China and USA will be very different (Wang et al., 2013).

Leafy vegetables, as one of the important sources of human nutrients, is very important for maintaining human health (Uusiku et al., 2010), and the difference of food habits and preference will result into difference of varieties of leafy vegetables from China and the United States. Lettuce (Lactuca sativa L.), commonly known as leafy lettuce and called as goose vegetable, belongs to Lactuca and rogynus of Compositae. Lettuce is an annual or biennial herbaceous crops, whose leaf is long and obovate. Lettuce, crisp and refreshing and slightly sweet, often is used for raw food. Lettuce mainly cultured in Europe, America, East Asia, large areas of China's southeast coast. Most lettuce from supermarkets of the USA has more stems, less leaves, and harder than that from Chinese supermarkets and its taste is worse, vegetable taste is not dense, but its storage period is longer than Chinese lettuce.

However, the comparison of nutrient component contents of Chinese lettuce and American lettuce has not been reported. In this paper, the main nutritional components of lettuce from the supermarkets of the two countries were compared, in order to provide the corresponding suggestions for the two countries' diet and the health of the people. 


\section{MATERIALS AND METHODS}

\section{Materials and instruments}

Chinese lettuce (cv: Lvguan No.1) was brought from Chaoshifa supermarket of Yuaningyuan West road of Beijing, and American lettuce (cv: Ridgeline) was brought from Stop and shop supermarket (440 Russell Street, Hadley, MA 01035, Super Stop \& Shop \#0095), Big Y supermarkets (University Drive, Amherst, MA 01002). The ICP-MS instrument was the PQ Excell instrument (ELAN DRCII, PE Company, USA).

\section{Experimental method}

The protein was determined, using bovine serum albumin as the standard protein according to method of Bradford (1976).

Total dietary fiber was analyzed according to AOAC methods (AOAC, 2003).

The fatty acids were extracted by Soxhlet extractor.

The ICP-MS parameters were just referred to Zhang and Rui (2012).

\section{RESULTS AND DISCUSSIONS}

\section{Comparison of shelf life in Chinese and American lettuce}

Under the condition of $0-4^{\circ} \mathrm{C}$, the Chinese lettuce can only store 4-8 days, the American lettuce can store 10-20 days.

Chinese lettuce has more leaves and less stalks than American lettuce; and the American lettuce were harder than Chinese lettuce.

\section{Comparison of moisture content in Chinese and American lettuce}

Moisture contents of Chinese lettuce and American lettuce showed that Chinese lettuce contained more moisture than American lettuce (Fig. 1), which is consistent to that Chinese lettuce has more leaves and less stalks than American lettuce.

More moisture, more leaves and less stalks should be the reasons why storage period of Chinese lettuce is shorter than American lettuce.

\section{Comparison of major nutrient components in Chinese and American lettuce}

Protein, fatty acids, carbohydrate, dietary fiber are the four important major nutrient components. The results showed that Chinese lettuce significantly contained more protein and fatty acids than American lettuce, but contained less carbohydrate and dietary fiber (Table 1). Because these major nutrient components have different functions for human health, these significant difference could cause nutritional imbalance of consumer. The suggestion is that the different varieties of lettuce should be exchanged for food, which can make the human body nutritional balance of Protein, fatty acids, carbohydrate, dietary fiber.

\section{Comparison of trace elements in Chinese and American lettuce}

The results in Table 2 showed that concentrations of most trace elements $(\mathrm{Ca}, \mathrm{Fe}, \mathrm{Zn}, \mathrm{Se}, \mathrm{Cu})$ in Chinese lettuce were significantly higher than American lettuce except Mn. Especially Se in lettuce from China was several times higher than that from China, which is very important for antioxidant and cancer prevention. In terms of trace elements, the Chinese lettuce is better than American lettuce.

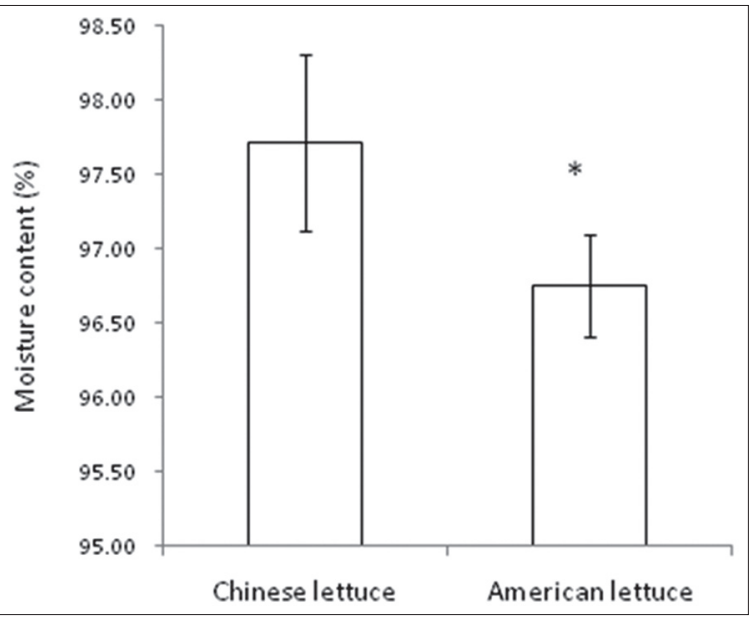

Fig 1. Moisture contents of Chinese lettuce and American lettuce. Note: *Represent significant difference from Chinese lettuce

Table 1: Contents of Protein, Fatty acids, Carbohydrate, Dietary fiber in Chinese lettuce and American lettuce (100 g)

\begin{tabular}{lcc}
\hline Items & Chinese lettuce & American lettuce \\
\hline Protein $(\mathrm{g})$ & $1.27 \pm 0.048$ & $0.85 \pm 0.051^{*}$ \\
Fatty acids $(\mathrm{g})$ & $0.36 \pm 0.024$ & $0.21 \pm 0.017^{\star}$ \\
Carbohydrate $(\mathrm{g})$ & $2.15 \pm 0.091$ & $3.27 \pm 0.088^{*}$ \\
Dietary fiber $(\mathrm{g})$ & $0.72 \pm 0.041$ & $1.22 \pm 0.065^{*}$ \\
\hline
\end{tabular}

Note: *Represents significant difference from Chinese lettuce $(P<0.05)$

Table 2: Contents of trace elements in Chinese lettuce and American lettuce $(100 \mathrm{~g})$

\begin{tabular}{lcc}
\hline Items & Chinese lettuce & American lettuce \\
\hline $\mathrm{Ca}(\mathrm{mg})$ & $30.4 \pm 1.55$ & $17.5 \pm 0.93^{*}$ \\
$\mathrm{Fe}(\mu \mathrm{g})$ & $843.6 \pm 17.21$ & $451.5 \pm 18.76^{*}$ \\
$\mathrm{Zn}(\mu \mathrm{g})$ & $266.6 \pm 9.29$ & $160.1 \pm 7.34^{*}$ \\
$\mathrm{Se}(\mu \mathrm{g})$ & $1.15 \pm 0.05$ & $0.14 \pm 0.02^{*}$ \\
$\mathrm{Cu}(\mu \mathrm{g})$ & $33.1 \pm 2.17$ & $27.6 \pm 1.86^{*}$ \\
$\mathrm{Mn}(\mu \mathrm{g})$ & $131.2 \pm 6.55$ & $146.9 \pm 5.91^{*}$ \\
\hline
\end{tabular}

Note: *Represents significant difference from Chinese lettuce $(\mathrm{P}<0.05)$ 
The concentrations of trace elements in vegetables depend on the content of soil (Guo Shufang, Xiang Lanyu, Zhuo $\mathrm{Li}$ and Lin Zhongquan. Study on the Relativity of Main Trace Elements in the Soil and Vegetables from Neijiang. J. Anhui Agri.Sci. 2008, 36(13):5249-5250) and fertilizer, sometimes vegetable varieties. We recommend that the lettuce farmers in United States use more trace element fertilizer, especially elements $\mathrm{Ca}, \mathrm{Fe}, \mathrm{Zn}, \mathrm{Se}$ and $\mathrm{Cu}$.

\section{CONCLUSIONS}

The nutritional contents in Chinese lettuce and American lettuce were very different, which should be relative to the food preference and nutritional balance of different countries. Chinese lettuce contained more protein and fatty acids than American lettuce, but less carbohydrate and dietary fiber; and concentrations of most trace elements detected in Chinese lettuce were higher than American lettuce except Mn.

\section{ACKNOWLEDGEMENTS}

The project was supported by the National Natural Science Foundation of China (No.41371471) and NSFCGuangdong Joint Fund (U1401234). The authors gratefully acknowledge technical assistance with ICP-MS provided by Ouyang Li from Beijing University.

\section{Competing financial interests}

The authors declare that they have no competing interests.

\section{Author contributions}

Shi Xueping and Rui Yukui designed and carried the experiments, Shi Xueping Fang Yu, Caiyun Jiang, Hongtao Wang and Rui Yukui wrote and revised the manuscript.

\section{REFERENCES}

AOAC. 2003. Total dietary fiber in foods, enzymatic-gravimetric method. In: Horwitz, W., (Ed.), Official Methods of Analysis, $17^{\text {th }}$ ed. AOAC International, Gaithersburg, MD.

Bradford, M. M. 1976. A rapid and sensitive method for the quantitation of microgram quantities of protein utilizing the principle of protein-dye binding. Anal. Biochem. 72: 248-254.

Gerber Mariette, J. and T. Sophie. 2009. Obesity in mediterranean countries: Food and/or food habits? Ann. Nutr. Metab. 55: 271-271.

Kim, Y. Y., J. H. Yoo, K. H. Park and S. W. Lee. 2012. The effects of constitutional food preference on health status of the twenties. J. Sasang Constitut. Med. 24(2): 31-38.

Uusiku Nangula, P., O. Andre, K. G. Duodu, M. J. Bester and M. Faber. 2010. Nutritional value of leafy vegetables of SubSaharan Africa and their potential contribution to human health: A review. J. Food Compos. Anal. 23(6): 499-509.

Velardo, S. 2015. The nuances of health literacy, nutrition literacy, and food literacy. J. Nutr. Educ. Behav. 47(4): 385-U122.

Wang, H. Y., F. Feng, Y. Guo, S. M. Shuang and M. M. F. Choi. 2013. HPLC-UV quantitative analysis of acrylamide in baked and deep-fried Chinese foods. J. Food Compos. Anal. 31(1): 7-11.

Zhang, H. X. and Y. K. Rui. 2012. Determining mineral elements in four kinds of grains from Beijing market by ICP-MS simultaneously. J. Saudi Chem. Soc. 16(1): 31-33. 